\title{
Analisis Kebutuhan Investasi Sektor Potensial dalam Mendorong Pertumbuhan Ekonomi di Kabupaten Lamongan Pada Tahun 2020
}

\author{
Muhamad Mujib \\ Mahasiswa FEBI UINSA Surabaya | \\ muhamadmujib667@gmail.com
}

Penelitian yang berjudul "Analisis Kebutuhan Investasi Sektor Potensial Dalam Mendorong Pertumbuhan Ekonomi Di Kabupaten Lamongan Pada Tahun 2020" ini bertujuan untuk menjawab apa saja sektor ekonomi potensial di Kabupaten Lamongan dan berapa kebutuhan investasinya dalam rangka mendorong pertumbuhan ekonomi di Kabupaten Lamongan.

Metodologi penelitian yang digunakan adalah pendekatan kuantitatif deskriptif. Alat analisis yang digunakan yaitu Location Quotient (LQ) dan Icremental Capital Output Ratio (ICOR). Analisis LQ digunakan untuk menentukan sektor potensial dan ICOR digunakan untuk menentukan kebutuhan investasi dari setiap sektor. Data yang digunakan merupakan data sekunder yang diambil secara langsung dari website Badan Pusat Statistik (BPS).

Hasil penelitian ini menyimpulkan terdapat delapan sektor unggulan yang ada di Kabupaten Lamongan yaitu (1) sektor pertanian, kehutanan, perikanan, (2) sektor pengadaan air, pengelolaan sampah, limbah dan daur ulang, (3) sektor konstruksi, (4) sektor informasi dan komunikasi, (5) sektor real estate, (6) sektor administrasi pemerintahan, pertahanan dan jaminan sosial wajib, (7) sektor jasa kesehatan dan kegiatan sosial, (8) sektor jasa lainnya.

Hasil perhitungan ICOR dapat digunakan untuk menghitung kebutuhan investasi untuk mendorong pertumbuhan output sebesar $1 \%$. Kebutuhan investasi sektor potensial di Kabupaten Lamongan yaitu (1) sektor pertanian, kehutanan sebesar, perikanan sebsar 575,52 miliar, (2) sektor pengadaan air, pengelolaan sampah, limbah dan daur ulang sebesar 1,65 miliar, (3) sektor konstruksi sebsar 193,92 miliar, (4) sektor informasi dan komunikasi sebsar 86,80 miliar, (5) sektor real estate sebesar 22,59 miliar, (6) sektor administrasi 
Muhamad Mujib

pemerintahan, pertahanan dan jaminan sosial wajib sebesar 271,68 miliar, (7) sektor jasa kesehatan dan kegiatan sosial sebesar 7,97 miliar, (8) sektor jasa lainnya sebesar 30 miliar.

Keywords: Sektor Potensial, Investasi, Pertumbuhan Ekonomi. 


\section{Pendahuluan}

Kondisi perekonomian Kabupaten Lamongan berada di posisi ke 12 dari 29 kabupaten di Jawa Timur pada tahun 2017. Jumlah investasi dari tahun 2014 hingga tahun 2017 memiliki tren yang positif. Akan tetapi meskipun memiliki tren yang positif kegiatan investasi belum mampu memberikan dampak yang signifikan terhadap laju pertumbuhan ekonomi Kabupaten Lamongan. Hal tersebut ditunjukkan dengan laju pertumbuhan ekonomi Kabupaten Lamongan yang memiliki tren negatif. Kondisi ini berkebalikan dengan teori ekonomi yang menyatakan bahwa penambahan stok modal (investasi) mampu mendorong laju pertumbuhan ekonomi suatu wilayah.

Besar kontribusi investasi total dari tahun 2014 hingga 2017 Kabupaten Lamongan terhadap total investasi Jawa Timur rata-rata sebesar $1.91 \%$. \%. Bahkan jika dilihat dari realisasi Pembentukan Modal Dalam Negeri (PMDN) non fasilitas di Jawa Timur, Kabupaten Lamongan hanya menyumbang kontribusi investasi dalam negeri sebesar $0.62 \%$ dari total PMDN Jawa Timur ${ }^{1}$. Kondisi perekonomian Kabupaten Lamongan perlu untuk ditingkatkan lagi. Memperbaiki iklim investasi dalam rangka mendorong pertumbuhan ekonomi Kabupaten Lamongan.

Kondisi tersebut diduga terjadi karena kurang tepatnya suatu daerah dalam mengalokasikan dana investasi yang masuk. Salah satu strategi yang bisa digunakan Pemerintah Kabupaten Lamongan yaitu menentukan kebutuhan investasi dari sektor-sektor potensial yang terdapat di Kabupaten Lamongan. Sektor potensial merupakan sektor unggulan dimana output dari sektor tersebut mempunyai daya saing atau keuntungan kompetitif yang tinggi dibandingkan sektor lain. Keunggulan kompetitif yang dimiliki oleh sektor unggulan memungkinkan produk dari sektor tersebut dipasarkan ke luar daerah maupun ke pasar global². Dengan adanya kegiatan

${ }^{1}$ Tim Badan Perencanaan Pembangunan Daerah, Data Dinamis Provinsi Jawa Timur Triwulan I 2018 (Jawa Timur: BAPPEDA Jawa Timur, 2019), 100-110. ${ }^{2}$ Sapriadi, Hasibiuallah, "Analisis Penentuan Sektor Unggulan Perekonomian Kabupaten Bulukumba”, Iqtisaduna, No. 1, Vol. 1 (Juni 2015), 75 
investasi akan memberikan sebuah input dalam proses produksi sehingga produk yang dihasilkan akan semakin meningkat dan terjadi pertumbuhan.

\section{Landasan Teori}

1. Teori Ekonomi Pembangunan

Ekonomi Pembangunan merupakan usaha-usaha pembangunan yang dilakukan khususnya oleh negaranegara yang sedang berkembang untuk memperbaiki kondisi negara ke keadaan yang lebih baik lagi. Orientasi dari ekonomi pembangunan yaitu bagaimana memperbaiki dan meningkatkan tingkat kesejahteraan masyarakat negara tersebut agar kesejahteraan mereka bisa sama dengan kesejahteraan negara maju. Perhatian pembangunan untukmeningkatkan taraf hidpmasyarakat ditekankan pada penegntasan kemiskinan, pengangguran, dan ketimpangan.

Secara umum pembangunan ekonomi membahas tantang kebijakan pemerintah (moneter maupun fiscal), ekspor-impor, pertumbuhan ekonomi, dan kebijakan makro lainnya. Ruang lingkup pembangunan ekonomi meliputi seluruh wilayah dari suatu negara. Dalam ilmu ekonomi pembangunan dapat mengklasifikasi daerahdaerah maju dan daerah-daerah tertinggal serta melihat keterkaitan antara wilayah satu dengan lainnya.

Perhatian penting dari pembangunan ekonomi yaitu bagaimana suatu negara melakukan proses perubahan kondisi hidup masyarakat ke arah yang lebih baik lagi. Perubahan kondisi hidup masyarakat di ukur dengan tingkat pendapatan perkapita suatu negara. Oleh karena itu pembangunan ekonomi sangat erat kaitannya dengan pendapatan perkapita dan pendapatan nasional. Pendapatan perkapita merupakan pendapatan rata-rata yang diperoleh setiap individu sedangkan pendapatan nasional merupakan total output (barang dan jasa) yang dihasilkan oleh suatu negara dalam jangka waktu satu tahun. Peningkatan pendapatan perkapita dan pendapatan nasional menjadi alat ukur untuk mengukur 
tingkat kesejahteraan masyarakat. ${ }^{3}$

2. Teroi Pembangunan Ekonomi Daerah

Rahardjo Adisasmita (2005) mengungkapkan bahwa pembangunan ekonomi wilayah merupakan sebuah fungsi dari sumber daya alam, sumber daya manusia, investasi, sarana dan prasarana pembangunan, transportasi, komponen industri, teknologi, kegiatan ekonomi wilayah, keuangan daerah, kewirausahaan, kelembagaan daerah, dan lingkungan pembangunan.

Tujuan dari dilakukannya proses pembangunan ekonomi suatu wialayah yaitu untuk menciptakan pertumbuhan ekonomi setinggi-tingginya, mengurangi jumlah kemiskinan, dan mengurangi angka ketimpangan antar wilayah. Oleh karena itu pembanguna ekonomi harus mampu mencipatkan lapangan kerja baru bagi masyarakat di suatu wilayah yang dapat memberikan pendapatan untuk digunakan memenuhi kebutuhan sehari-hari.

Pembangunan ekonomi daerah dapat dilihat dari berbagai segi, yang pertama dari pembangunan sektoral. Pembangunan sektoral merupakan pembangunan yang memprioritaskan pada sektor potensial suatu daerah, dimana sektor potensial merupakan sektor yang memberikan kontribusi yang besar bagi PDRB wilayah yang bersangkutan. Kedua, pembangunan ekonomi kota dan desa sebagai pusat kegiatan sosial ekonomi wilayah tersebut. Ketiga, pembangunan daerha dilihat dari campur tangan pemerintah. Arah dan strategi pembangunan daerah akan berjalan dengan baik jika pemerintah daerah tersebut mampu menjalankan tugas mereka dengan baik pula. Dengan diberlakukannya otonomi daerah, interverensi pemerintah pada proses pembanunan daerah menjadi sangat urgent karena arah dan strategi pembangunan daerah ditentukan oleh daerah masing-masing. Oleh karena itu kebijakan-

\footnotetext{
${ }^{3}$ Hilal Almulaibari, “Analisis Potensi Pertumbuhan Ekonomi Kota Tegal Tahun 2004-2008” (Skripsi

- Universitas Diponegoro Semarang, 20I I), I2.
} 
kebijakan dari pemerintah daerah akan sangat menetukan berhasil tidaknya keberlangsungan proses pembangunan ekonomi daerah yang bersangkutan. ${ }^{4}$

3. Teori Pertumbuhan Ekonomi Wilayah

Pertumbuhan ekonomi wilayah merupakan peningkatan jumlah total output wilayah (PDRB) dalam jangka waktu satu periode. Pertumbuhan ekonomi wilayah juga mencerminkan kenaikan pendapatan dan nilai tambah yang dimilki oleh setiap individu yang tinggal di wilayah tersebut ${ }^{5}$. Pertumbuhan ekonomi juga menjadi sebuah indikator penting dalam menentukan tingkat kesejahteraan masyarakat suatu daerah. Pertumbuhan ekonomi suatu daerah mampu mencerminkan bagaimana kehgiatan ekonomi daerah tersebut berjalan. Semakin tinggi pertumbuhan ekonomi suatu daerah maka produksi barang dan jasa yang dilakukan masyarakat daerah tersebut semakin meningkat, sehingga mampu meningkatkan pendapatan masyarakat daerah yang mengakibatkan kehidupan masyarakat daerah tersebut semakin makmur. Dengan demikian pertumbuhan ekonomi daerah dapat menjadi alat ukur keberhasilan proses pembangunan daerah yang bersangkutan. ${ }^{6}$

Thomas Robert Malthus yang merupakan tokoh ekonomi mengemukakan bahwa peningkatan taraf hidup masyarakat suatu negara/wilayah dapat dicapai dengan pertumbuhan ekonomi yang tinggi. Jumlah total output yang dihasilkan oleh tenaga kerja di suatu negara/daerah mampu merefleksikan tingkat kesejahteraan suatu

\footnotetext{
${ }^{4}$ Aditya Nugraha Putra, "Analisis Potensi Ekonomi Kabupaten dan Kota di Provinsi Daerah Istimewa Yogyakarta” (Skripsi - Universitas Islam Negeri Syarif Hidayatullah, 2013), 9-10

${ }^{5}$ Hilal Almulaibari, "Analisis Potensi Pertumbuhan Ekonomi Kota Tegal Tahun 2004-2008" (Skripsi - Universitas Diponegoro Semarang, 2011), 17

${ }^{6}$ Ekaristi Jekna Mangilaleng, Debby Rotinsulu, Wensy Rompas, "Analisis Sektor Unggulan Kabupaten Minahasa Selatan", Jurnal Berkala Ilmiah Efisiensi, No. 04, Vol. 15 (April 2015), 195.
} 
negara/daerah tersebut. Oleh karena itu semkain tinggi pertumbuhan jumlah total output yang dihasilkan suatu negara/daerah, maka tingkat kesejahteraan masyarakat negara/daerah tersebut juga akan semakin tinggi. ${ }^{7}$

4. Investasi Dalam Pembangunan

Dalam kegiatan perekonomian, investasi merupakan pengeluaran untuk membeli barang-barang modal dan komponen produksi untuk meningkatkan kuantitas output yang diproduksi. Sumber investasi dapat dibagi menjadi dua jenis yaitu investasi yang bersumber dari luar negeri dan investasi yang bersumber dari dalam negeri. Investasi yang bersumber dari luar negeri sering disebut dengan Penanaman Modal Asing (PMA). Sedangkan investasi yang bersumber dari dalamnegeri sering disebut dengan Pembentukan Modal Dalam Negeri (PMDN). Kedua investasi tersebut mempunyai manfaat yang sama yaitu mampu mendorong produktifitas lebih tinggi. ${ }^{8}$

Perekonomian dikatakan berkembang apabila kegiatan ekonomi mampu melakukan proses akumulasi modal secara terus menerus dalam mendorong penambahan komponen produksi. Untuk mendukung terbentuknya akumulasi modal, masyarakat didorong untuk menggunakan sisa pendapatan yang telah dipakai konsumsi untuk digunakan investasi. ${ }^{9}$

Dalam rangka meningkatkan pertumbuahn ekonomi daerah, pemilihan satrategi dalam menarik masuknya dana investasi harus dirumusakan dengan baik. Pemilihan strategi yang tepat dalam menarik

${ }^{7}$ Aditya Nugraha Putra, “Analisis Potensi Ekonomi Kabupaten dan Kota di Provinsi Daerah Istimewa Yogyakarta” (Skripsi - Universitas Islam Negeri Syarif Hidayatullah, 2013), 18-20

${ }^{8}$ Cok Istri Sinta Regina Trisnu, Ida Bagus Putu Purbadharmaja, "Pengaruh PMDN dan PMA Terhadap PDRB di Provinsi Bali", E-Jurnal Ekonomi Pembangunan Universitas Udayana, No. 3, Vol. 3 (Maret 2014), 89-90.

9 Tia Astiartie, "Analisis Kebutuhan Investasi Sektor-sektor Ekonomi Unggulan dalam Upaya Peningkatan Tenaga Kerja di Kota Surakarta” (Skripsi - Universitas Sebelas Maret Surakarta, 2010), 31-32. 
investasi dapat meningkatkan efisiensi dalam kegiatan ekonomi. Oleh karena itu sebelum mengalokasikan dana investasi yang masuk maka harus ditentukan terlebih dahulu arah alokasi investasi tersebut. Ada beberapa prinsip dalam mengalokasikan dana investasi yaitu:

1. Investasi sebisa mungkin dialokasikan ke kegitan produksi yang paling produktif.

2. Investasi di alokasikan ke sekotr ekonomi padat karya, dimana menggunakan faktor produksi tenaga kerja lebih banyak dari pada faktor produksi modal.

3. Alokasi investasi harus melalui tahapan seleksi sehingga menghasilkan produk-produk yang dibutuhkan masyarakat. Investasi dialokasikan pada industri yang mampu menyerap valuta asing.

Oleh karena itu menjaga iklim investasi yang baik mampu merangsang terjadinya pertumbuhan ekonomi. Oleh karena itu perbaikan iklim investasi suatu daerah menjadi tugas dari setiap daerah untuk untuk meningkatkan daya saing investasi.

Kalangan dunia usaha merupakan salah satu pelaku terbesar dalam dunia investasi. Persepsi dunia usaha dalam mengambil perlu diketahui oleh pemerintah daerah sama halnya dengan mengetahui bagaimana karakteristik dan kebutuhan para investor dalam menentukan pilihan lokasi investasi. Dengan mengetahui karakteristik dan kebutuhan para investor maka pemerintah daerah akan semakin mudah dalam merumuskan kebijakan-kebijakan yang menunjang peningkatan daya saing investasi daerah yang bersangkutan. Ada beberapa faktor yang mempengaruhi dunia usaha menanamkan modal (investasi) di suatu wilayah. Faktor-faktor tersebut yaitu faktor ekonomi, infrastruktur, politik dan kelembagaan, soial dan budaya. Faktor-faktor tersebut juga diyakini mampu membentuk daya saing suatu wilayah. ${ }^{10}$

${ }^{10}$ Badan Pusat Statistik Provinsi Banten, Incremental Capital Output Ratio (ICOR) Provinsi Banten 2014 (Banten: BPS Provinsi Banten, 2015), 3-4. 


\section{Hipotesa Dan Jenis Penelitian}

1. Hipotesis

1) H1 : Diduga tidak terdapat sektor potensial di Kabupaten Lamongan

2) H2 : Diduga terdapat sektor potensial di Kabupaten Lamongan

2. Kerangka Penelitian

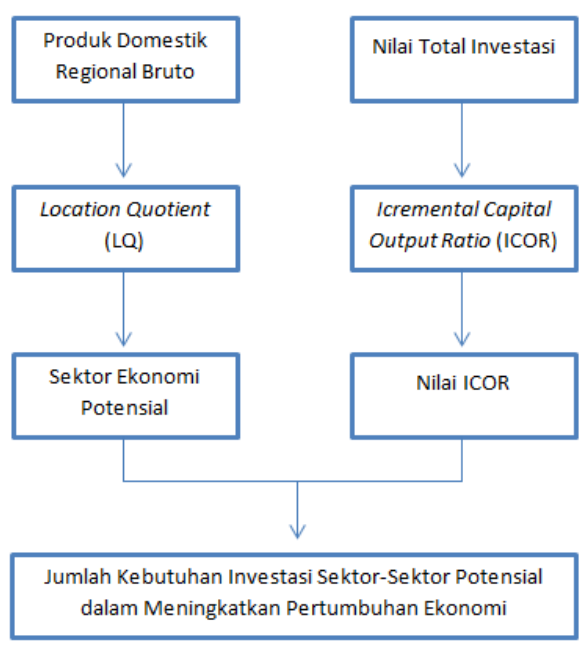

3. Jenis Penelitian

Penelitian ini merupakan jenis penelitian kuantitatif, dimana cara memperoleh data, pengolahan data, dan penyajian hasil analisis dilakukan dengan angka. Penelitian ini termasuk kedalam penelitian deskriptif karena mampu menggambarkan kondisi suatu wilayah. 


\section{Analisa Data}

1. Metode Analisis Data

Penelitian ini menggunakan dua metode yaitu analisis Location Quotient (LQ) dan Incremental Capital Output Ratio (ICOR). Metode LQ digunakan untuk menganalisis sektor ekonomi potensial di suatu wilayah. Sedangkan analisis ICOR digunakan untuk menganalisis kebutuhan investasi dari sektor potensial tersebut.

\section{Pembahasan}

Perhitungan LQ dilakukan dengan pendekatan perbandingan yaitu membandingkan kondisi perekonomian suatu lingkup wilayah yang kecil dengan lingkup wilayah yang lebih besar. Sektor ekonomi wilayah yang mempunyai nilai perbandingan yang tinggi merefleksikan bahwa sektor tersebut mempunyai keunggulan komparatif lebih tinggi dibandingkan dengan sektor yang sama dalam lingkup yang lebih luas.

Hasil perhitungan $L Q$ menghasilkan tiga kriteria. Kriteria pertama, jika nilai $L Q$ lebih dari satu $(L Q>1)$ maka sektor tersebut merupakan sektor potensial dimana output dari sektor tersebut mampu memenuhi kebutuhan dalam daerah dan luar daerah. Kriteria kedua, jika nilai $L Q$ sama dengan satu $(L Q=1)$ maka sektor tersebut tergolong sektor non potensial. Output dari sektor non potensial hanya mampu memenuhi kebutuhan dalam daerah sehingga sektor tersebut tidak mampu memberikan pendapatan dari luar daerah. Kriteria ketiga, apabila nilai $L Q$ kurang dari satu $(L Q<1)$ maka sektor tersebut termasuk sektor non potensial. Produksi dari sektor non potensial belum mampu memenuhi kebutuhan dalam daerah sehingga memerlukan pasokan atau impor dari daerha lain.

Hasil perhitungan $L Q$ menunjukkan bahwa terdapat delapan sektor ekonomi potensial di Kabupaten Lamongan. Delapan sektor ekonomi potensial tersebut yaitu (1) sektor pertanian, kehutanan, perikanan, (2) sektor pengadaan air, pengelolaan sampah, limbah dan daur ulang, (3) sektor konstruksi, (4) sektor informasi dan komunikasi, (5) sektor real estate, (6) sektor administrasi pemerintahan, pertahanan dan jaminan sosial wajib, (7) sektor jasa kesehatan dan kegiatan sosial, (8) sektor jasa lainnya. 
Analisis Incremental Capital Output Ratio (ICOR) digunakan untuk mengetahui seberapa efisien kegiatan investasi yang dilakukan di suatu daerah. Semakin tinggi efisiensi sektor ekonomi maka semakin tinggi pula tingkat produktifitas sektor tersebut dalam menghasilkan barang dan jasa. Tingginya produktifitas suatu sektor akan memacu produksi barang dan jasa semakin banyak sehingga mampu merangsang pertumbuhan output dari sektor tersebut.

Nilai ICOR Sektor Potensial Kabupaten Lamongan|

\begin{tabular}{|c|c|c|c|c|c|}
\hline $\begin{array}{c}\text { Sektor Potensial } \\
\text { Lamongan }\end{array}$ & $\begin{array}{l}\text { Koefisien } \\
\text { ICOR } \\
2013\end{array}$ & $\begin{array}{c}\text { Koefisien } \\
\text { ICOR } \\
2014\end{array}$ & $\begin{array}{c}\text { Koefisien } \\
\text { ICOR } \\
2015\end{array}$ & $\begin{array}{c}\text { Koefisien } \\
\text { ICOR } \\
2016\end{array}$ & $\begin{array}{c}\text { Rata- } \\
\text { rata } \\
\text { Nilai } \\
\text { ICOR }\end{array}$ \\
\hline $\begin{array}{l}\text { Pertanian, } \\
\text { Kehutanan, dan } \\
\text { Perikanan }\end{array}$ & 5.70 & 6.51 & 7.05 & 7.61 & 6.72 \\
\hline $\begin{array}{l}\text { Pengadaan Air, } \\
\text { Pengelolaan } \\
\text { Sampah, Limbah } \\
\text { dan Daur Ulang }\end{array}$ & 4.36 & 9.23 & 6.02 & 6.06 & 6.42 \\
\hline Konstruksi & 0.82 & 6.43 & 19.05 & 5.29 & 7.90 \\
\hline $\begin{array}{l}\text { Informasi dan } \\
\text { Komunikasi }\end{array}$ & 4.41 & 4.85 & 4.73 & 4.80 & 4.70 \\
\hline Real Estate & 3.83 & 4.13 & 4.17 & 5.62 & 4.44 \\
\hline $\begin{array}{l}\text { Administrasi } \\
\text { Pemerintahan, } \\
\text { Pertahanan dan } \\
\text { Jaminan Sosial } \\
\text { Wajib }\end{array}$ & 19.24 & 80.56 & 5.44 & 7.88 & 28.28 \\
\hline $\begin{array}{l}\text { Jasa Kesehatan } \\
\text { dan Kegiatan } \\
\text { Sosial }\end{array}$ & 3.83 & 3.49 & 3.70 & 4.14 & 3.79 \\
\hline Jasa Lainnya & 7.09 & 4.51 & 4.71 & 9.73 & 6.51 \\
\hline
\end{tabular}

Tabel 1 memaparkan hasil perhitungan nilai ICOR dari tujuh sektor potensial di Kabupaten Lamongan dari tahun 20132016. Hasil perhitungan tersebut menujukkan bahwa sektor jasa kesehatan dan kegiatan sosial memiliki nilai ICOR yang paling rendah yaitu sebesar 3,79, disusul dengan sektor real estate dan sektor informasi dan komunikasi dengan rata-rata nilai ICOR masing-masing sebesar 4,44 dan 4,70. Nilai ICOR yang rendah menujukkan sektor-sektor tersebut telah efisien dalam menghasilkan barang dan jasa. Ketiga sektor ini membutuhkan investasi yang relatif rendah untuk menghasilkan satu unit barang dan jasa. 
Sedangkan sektor yang memiliki nilai ICOR paling besar yaitu sektor administrasi pemerintahan, pertahanan dan jaminan sosial wajib dengan rata-rata nilai ICOR sebesar 28,28 . Dengan nilai ICOR yang tinggi dapat disimpulkan bahwa investasi yang ditanamkan di sektor ini kurang efisien karena membutuhkan lebih banyak investasi untuk menghasilkan satu unit barang dan jasa yang diproduksi oleh sektor tersebut.

Dalam rangka meningkatkan pertumbuhan ekonomi Kabupaten Lamongan maka harus diketahui berapa kebutuhan investasi yang dibutuhkan. Kebutuhan investasi perlu untuk diketahui untuk mempermudah merealisasikan target pertumbuhan ekonomi yang dinginkan oleh Kabupaten Lamongan.

Kebutuhan investasi dapat dihitung dengan cara mengalikan nilai koefisien ICOR dan perubahan output yang tercapai. Hasil dari perhitungan tersebut akan menghasilkan investasi minimal yang harus diperoleh oleh suatu daerah untuk mencapai target pertumbuhan.

Berdasarkan Rencana Pembangunan Jangka Menengah Daerah (RPJMD) Kabupaten Lamongan 2016-2021, Kabupaten Lamongan menargetkan petumbuhan ekonomi sebesar 5,5\%$6,5 \% .^{11}$

Oleh karena itu peranan sektor unggulan sangat diperlukan dalam mendorong pertumbuhan ekonomi Kabupaten Lamongan yang ditargetkan 6,5\%. Penambahan nilai investasi total dapat menjadi salah satu rencana strategis dalam mendongkrak pertumbuhan ekonomi di Kabupaten Lamongan pada tahun 2020.

${ }^{11}$ Pemerintahan Kabupaten Lamongan, Peraturan Daerah Kabupaten Lamongan tentang Rencana Pembangunan Jangka Menengah Daerah (RPJMD) Kabupaten 2016-2021 (PEMKAB Lamongan,2015), V190. 
Kebutuhan Investasi Sektor Potensial untuk Mendorong Pertumbuhan Ekonomi 6.5\% (miliar rupiah).|

\begin{tabular}{|l|r|}
\multicolumn{1}{|c|}{ Sektor Potensial Lamongan } & $\begin{array}{c}\text { Kebutuhan } \\
\text { Investasi 2020 }\end{array}$ \\
\hline Pertanian, Kehutanan, dan Perikanan & 3280.45 \\
\hline Pengadaan Air, Pengelolaan Sampah, Limbah dan Daur Ulang & 1105.33 \\
\hline Konstruksi & 494.75 \\
\hline Informasi dan Komunikasi & 128.77 \\
\hline Real Estate & 1548.58 \\
\hline Administrasi Pemerintahan, Pertahanan dan Jaminan Sosial Wajib & 45.46 \\
\hline Jasa Kesehatan dan Kegiatan Sosial & 170.99 \\
\hline Jasa Lainnya & \\
\hline Sumber: BPS Kabupaten Lamongan & \\
\hline
\end{tabular}

kebutuhan investasi dari setiap sektor potensial untuk mencapai target pertumbuhan ekonomi di Kabupaten Lamongan sebesar 6,5\%. Untuk mencapai target tersebut, pertumbuhan dari setiap sektor potensial di Kabupaten Lamongan harus tumbuh sebesar 5,7\% pada tahun 2020 dan menggunakan asumsi bahwa pertumbuhan sektor lain (sektor non potensial) tetap.

\section{Penutup}

Berdasarkan hasil analisis data dan pembahasan mengenai analisa kebuthan investasi sektor-sektor potensial di Kabupaten Lamongan maka dapat ditemukan beberapa kesmipulan sebagai berikut:

Terdapat sektor potensial dari sektor-sektor ekonomi di Kabupaten Lamongan yaitu (1) sektor pertanian, kehutanan, perikanan, (2) sektor pengadaan air, pengelolaan sampah, limbah dan daur ulang, (3) sektor konstruksi, (4) sektor informasi dan komunikasi, (5) sektor real estate, (6) sektor administrasi pemerintahan, pertahanan dan jaminan sosial wajib, (7) sektor jasa kesehatan dan kegiatan sosial, (8) sektor jasa lainnya.

Kebutuhan Investasi masing masing sektor pada tahun 2020 yaitu (1) sektor pertanian, kehutanan dan perikanan membutuhkan investasi sebesar 3280,45 milar, (2) sektor pengadaan air pengelolaan sampah, limbah dan daur ulang 
membutuhkan investasi sebesar 9,38 miliar, (3) sektor konstruksi membutuhkan investasi sebesar 1105,33 miliar, (4) sektor informasi dan komunikasi membutuhkan investasi sebesar 494,75 miliar, (5) sektor real estaste membutuhkan investasi sebesar 128,77 miliar, (6) sektor administrasi pemerintahan, pertahanan dan jaminan sosial wajib membutuhkan investasi sebesar 1548,58 miliar, (7) sektor jasa kesehatan dan kegiatan sosial membutuhkan investasi sebesar 45,46 miliar, (8) sektor jasa lainnya membutuhkan investasi sebesar 170,99 miliar. 


\section{DAFTAR PUSTAKA}

Aditya Nugraha Putra. "Analisis Potensi Ekonomi Kabupaten dan Kota di Provinsi Daerah Istimewa Yogyakarta". Skripsi - Universitas Islam Negeri Syarif Hidauyatullah, 2013.

Arif Tison Situmorang. "Pengaruh Efisiensi Perekonomian Terhadap Pertumbuhan Ekonomi 32 Provinsi di Indonesia". Skripsi Universitas Diponegoro Semarang, 2011.

Badan Pusat Statistik Provinsi Banten. Incremental Capital Output Ratio (ICOR) Provinsi Banten 2014. Banten: BPS Provinsi Banten, 2015.

Cok Istri Sinta Regina Trisnu, Ida Bagus Putu Prbadharmaja. "Pengaruh PMDN dan PMA Terhadap PDRB di Provinsi Bali". E-Jurnal EP Unud, No. 3, Vol. 3 Maret 2014.

Dearmi Artis, Syaparuddin, Nurhayani. "Kajian ICOR Kabupaten Batanghari". Jurnal Paradigma Ekonomika. No. 1, Vol. 10. April 2015.

Dewi Karina, Prananda Navitas. "Arahan Pengembangan Ekonomi Kabupaten Lamongan Berdasarkan Sektor Unggulan Studi Kasus: Sektor Pertanian". Jurnal Teknik POMITS. No. 2, Vol. 3. 2014.

Ekaristi Jekna Mangilaleng, Debby Rotinsulu, Wensy Rompas. "Analisis Sektor Unggulan Kabupaten Minahasa Selatan". Jurnal Berkala Ilmiah Efisiensi, No. 04, Vol. 15. April 2015.

Haddy Suprapto. Metodelogi Penelitian untuk Karya Ilmiah. Yogyakarta: Gosyen Publishing, 2017.

Hardyanto. "Analisis Komoditas Unggulan Sektor Pertanian di Kabupaten Seluma Provinsi Bengkulu". Skripsi - Universitas Bengkulu. 2013.

Hilal Almulaibari. "Analisis Potensi Pertumbuhan Ekonomi Kota Tegal Tahun 2004-2008". Skripsi - Universitas Diponegoro Semarang, 2011.

https://setkab.go.id/kebocoran-vs-efisiensi-anggaran/ diakses pada 4 Juli 2019.

Komang Agus Triasta Putra, Luh Putu Aswitari. “Kebutuhan Investasi Sektor Basis Industri Per Kecamatan di Kabupaten Gianyar dalam Rangka One Village One Product" E-Jurnal EP Unud". No. 12, Vol. 2. Desember 2013. 
L Suparto LM. “Analisis Invesment Capital Output Ratio (ICOR) dalam Rangka Proyeksi Kebutuhan Investasi di Kabupaten Majalengka Tahun 2017-2019". Jurnal Ilmiah Manajemen dan Akuntansi, No. 1, Vol. 4. Januari-Juni 2017.

Miftakhu 1 Saleh. "Analisis Efisiensi Pertambahan Investasi Provinsi Jawa Tengah Tahun 2000-2013". Skripsi - Universitas Muhammadiyah Surakarta, 2014.

Mohamad Maulana. "Estimasi Incremental Capital Output Ratio (ICOR) untuk Perencanaan Investasi dalam Rangka Pembangunan Sektor Pertanian". Jurnal Agro Ekonomi, No. 2, Vol. 30. Oktober 2012.

Muhamad Farid Mahmud. "Incremental Capital Output Ratio: Barometer Efisiensi Perekonomian Nasinal". Jurnal Ekonomi Bisnis, No. 1, Vol. 1. April 2008.

Muhammad Budi Santoso. "Analisis Sektor Perokonomian Unggulan di Kabupaten Magelang Periode 2010-2014". Skripsi Universitas Islam Negeri Sunan Kalijaga Yogyakarta, 2017.

N. Gregory Mankiw Euston Quah Peter Wilson. Pengantar Ekonomi Makro. Jakarta: Salemba Empat, 2012.

Nudiatulhuda Mangun. "Analisis Potensi Ekonomi Kabupaten dan Kota di Provinsi Sulawesi Tengah". Tesis - Universitas Diponegoro Semarang, 2007.

Nurul Faizun, Muhammad Nasir, Nur Syechalad. “Analisis Kebutuhan Investasi Sektor Pertanian dalam Rangka Meningkatkan Pertumbuhan Ekonomi di Provinsi Aceh". Jurnal Ilmu Ekonomi Pascasarjana Universitas Syiah Kuala, No. 4, Vol. 2. November 2014.

Rachmat Hendayana. "Aplikasi Metode Location Quotient (LQ) dalam Penentuan Komoditas Unggulan Nasional". Informatika Pertanian, Vol. 12. Desember, 2003.

Sapriadi, Hasibullah. "Analisis Penentuan Sektor Unggulan Perekonomian Kabupaten Bulukumba". Iqtisaduna, No. 1, Vol. 1. Juni 2015.

Satriyo Pratomo. "Analisis Peran Sektor Pertanian Sebagai Sektor Unggulan di Kabupaten Boyolali". Skripsi-Universitas Sebelas Maret Surakarta, 2010.

Shofwatunnida. "Analisis Potensi Pertumbuhan Ekonomi Sektor Industri Pengolahan Non Migas di Provinsi Jawa Barat Periode 
2005-2009". Skripsi - Universitas Islam Negeri Syarif Hidayatullah Jakarta, 2011.

Siti Fatimah Nurhayati, Eny Kusumawati. "Identifikasi Sektor Unggulan Kabupaten Lamongan: Tahun 2006-2010". Telaah Bisnis. No.1. Vol. 14. Juli 2013.

Sri H. Susilowati, Prajogo U. Hadi, Supena Friyatno, dkk. "Estimasi Incremental Capital Output Ratio untuk Perencanaan Investasi dalam Rangka Pembangunan Sektor Pertanian". Jurnal Agro Ekonomi, No. 2, Vol. 30. September, 2012.

Sri Kumalaningsih. Metodelogi Penelitian. Malang: UB Press, 2012.

Tarigan Robinson. Ekonomi Regional Teori dan Aplikasi. Jakarta: Bumi Akasara, 2005.

Tia Astiartie. "Analisis Kebutuhan Investasi Sektor-sektor Ekonomi Unggulan dalam Upaya Peningkatan Tenaga Kerja di Kota Surakarta". Skripsi - Universitas Sebelas Maret Surakarta, 2010.

Tim Badan Perencanaan dan Pembangunan Derah Sumatra Barat. Investasi dan ICOR Provinsi Sumatra Barat 2000-2012. Sumatra Barat: BAPPEDA Provinsi Sumatra Barat, 2013.

Tim Badan Perencanaan Pembangunan Daerah. Data Dinamis Provinsi Jawa Timur Triwulan I 2018. Jawa Timur: BAPPEDA Jawa Timur, 2019.

Tim Badan Pusat Statistik (BPS) Kabupaten Lamongan. Kabupaten Lamongan dalam Angka 2018. Lamongan: BPS Kabupaten Lamongan, 2019.

Tim Badan Pusat Statistik Banten. Incremental Capital Output Ratio (ICOR) Provinsi Banten Tahun 2014. Banten: BPS Provinsi Banten, 2015.

Tim Badan Pusat Statistik Kabupaten Solok. Investasi dan Incremental Capital Output Ratio (ICOR) Kabupaten Silok Tahun 2000-2010. Solok: BPS Kabupaten Solok, 2011.

Tim Badan Pusat Statistik. Incremental Capital Output Ratio (ICOR) dan Incremental Labour Output Ratio (ILOR) Kabupaten Situbondo Tahun 2011. Situbondo: BPS Kabupaten Situbondo, 2012. Tomi Kuntara. "Analisis Incremental Capital Output Ratio dan Pertumbuhan Ekonomi Provinsi Jawa Timur". Skripsi-Universitas Lampung, 2016. 